\title{
Hypothalamic Sites of Leptin Action Linking Metabolism and Reproduction
}

\author{
José Donato, Jr. Roberta M. Cravo Renata Frazão Carol F. Elias \\ Department of Internal Medicine, Division of Hypothalamic Research, University of Texas Southwestern \\ Medical Center, Dallas, Tex., USA
}

\author{
Key Words \\ Hypothalamus · Hypothalamus-pituitary-gonad axis · \\ Gonadotropin-releasing hormone $\cdot$ Luteinizing hormone • \\ Metabolism
}

\begin{abstract}
A critical amount of energy reserve is necessary for puberty initiation, for normal sexual maturation and maintenance of cyclicity and fertility in females of most species. Therefore, the existence of circulating metabolic cues which directly modulate the hypothalamus-pituitary-gonad axis is predictable. The adipocyte-derived hormone leptin is one of these cues having been studied extensively in the context of regulating the reproductive physiology. Humans and mice lacking leptin (ob/ob) or leptin receptor (LepR, $d b / d b)$ are infertile. Leptin administration to leptin-deficient subjects and $o b / o b$ mice induces puberty and restores fertility. LepR is expressed in brain, pituitary gland and gonads, but studies using genetically engineered mouse models determined that the brain plays a major role. Recently, it has been made clear that leptin acts indirectly on gonadotropin-releasing hormone $(\mathrm{GnRH})$-secreting cells via actions on interneurons. However, the exact site(s) of leptin action has been difficult to determine. In this review, we discuss the recent advances in the field focused on the identification of potential site(s) or specific neuronal populations involved in leptin's effects in the neuroendocrine reproductive axis.
\end{abstract}

Copyright $\odot 2010$ S. Karger AG, Basel

\section{KARGER}

Fax +4161306 1234

E-Mail karger@karger.ch

www.karger.com
(C) 2010 S. Karger AG, Basel

Accessible online at: www.karger.com/nen

\section{Introduction}

A critical amount of energy reserve is necessary for puberty initiation, for normal sexual maturation and maintenance of cyclicity and fertility in females of most species $[1,2]$. Ovulation is usually suppressed when a mammal is in negative energy balance, whether that state is caused by inadequate food intake, excessive locomotor activity or increased thermoregulatory costs. If excessive leanness occurs in young women, puberty is often delayed [3]. Puberty is a complex process which involves changes in maturation of reproductive organs, physical manifestations of steroids hormones and establishment of the reproductive capacity [4]. The onset of puberty is marked by an increase in gonadotropin-releasing hormone $(\mathrm{GnRH})$ secretion in a defined temporal manner. When puberty develops normally, sexual maturity is achieved and the secretion of gonadotropins becomes pulsatile, consisting of variable but well defined secretory pulses across the estrous (menstrual) cycle. This pulsatile release of $\mathrm{GnRH}$ is obligatory to sustain normal gonadotropin synthesis and secretion, cyclicity and ovulation. Food restriction, excessive exercise and other energetic challenges suppress GnRH pulsatility, and thereby disrupt cyclicity and fertility, and may delay the onset of puberty $[3,5,6]$. Therefore, the existence of a number of metabolic cues which impinge on GnRH neurons is predictable. The adipocyte-derived hormone leptin is one of these cues having been studied extensively in the context of regulating the reproductive axis. 


\section{Leptin Action on Reproduction}

Mice lacking leptin $(o b / o b)$ or leptin receptor (LepR, $d b / d b)$ develop hyperphagic obesity, diabetes and a variety of neuroendocrine dysfunctions $[7,8]$. These mice exhibit low gonadotropin levels, incomplete development of reproductive organs and do not reach sexual maturation. Leptin treatment to $o b / o b$ mice, but not weight loss alone, induces puberty, maturation of the gonads, gonadotropin secretion and restores fertility $[9,10]$. Humans with mutations in leptin or LepR genes recapitulate most of the leptin-deficient reproductive phenotype observed in mouse models [11]. In leptin-deficient subjects, leptin treatment induced an increase in the levels of gonadotropins and estradiol, as well as enlargement of the gonads and normal pubertal development [11]. Leptin levels fall on starvation, a response that drives many of the neuroendocrine changes observed in this condition, including those related to the reproductive neuroendocrine axis [12]. Thus, during states of negative energy balance, as in fasting, animals from many species exhibit decreased luteinizing hormone (LH) levels. Leptin administration blunts the fasting-induced suppression of LH secretion and restores fertility [12-14]. In women with hypothalamic amenorrhea resulting from conditions of negative energy balance, leptin treatment increased pulse frequency and mean levels of $\mathrm{LH}$, ovarian volume, the number of dominant follicles and estradiol levels [15]. Therefore, also in humans sufficient levels of leptin are required for normal reproductive function.

An important aspect to be mentioned is that the infertility phenotype observed in animal models of leptin deficiency seems to be highly dependent on their genetic background. For example, obese $o b / o b$ mice crossed onto a BALB/cJ strain exhibited improvement of fertility [16]. This phenomenon appears to be sexually dimorphic, as ob/ob males on F2 generation are partially fertile, but females only show improvement of fertility following backcrossing of the $o b \mathrm{C} 57 \mathrm{BL} / 6 \mathrm{~J}$ mutation for 10 generations into the $\mathrm{BALB} / \mathrm{cJ}$ genetic background. Moreover, a series of studies performed in seasonal breeders have challenged the concept of leptin action in the reproductive physiology (reviewed in Schneider [17]). In female hamsters, fasting-induced decrease in leptin levels is not always followed by reproductive impairment. In addition, leptin treatment prevents fasting-induced anestrus in female hamster only when oxidable fuels (e.g. fatty acid or glucose) are available. In food restricted re-fed hamster and sheep, plasma leptin does not increase before the restoration of LH pulses and fertility $[17,18]$. These findings suggest the existence of species differences likely due to exposure to specific evolutionary constraints and development of distinct reproductive strategies. But it also remains unclear whether in these conditions leptin signaling, LepR expression, leptin's transport through the blood brain barrier or the levels of unbound circulating leptin are unchanged.

The LepR is expressed in many different organs and tissues, including every node of the hypothalamus-pituitary-gonad axis $[8,19]$. Thus, the ability of leptin to regulate reproduction might be attained by direct actions in several cell types. Nevertheless, using genetic strategies, studies showed that selective re-expression of LepR only in the brain of mice otherwise null for LepR restores fertility in both males and females [20]. These studies established that the brain plays a major role.

The direct action of leptin in GnRH neurons seemed reasonable, as in vitro studies reported the expression of LepR in immortalized GnRH (GT1) cells [21]. However, these findings have not been reproduced in vivo (fig. 1) and, therefore, leptin direct action in GnRH neurons remained controversial. More recently, with the availability of genetic mouse models which allow selective deletion of LepR from defined neuronal populations, this controversy appears to have come to an end. Mice with selective deletion of LepR from GnRH neurons exhibited normal puberty initiation, sexual maturity, fertility and normal litter sizes [22]. This study determined that if LepR is expressed in GnRH neurons - in low or technically undetectable levels - it is not required for leptin action in puberty initiation and in the coordinated control of the reproductive function. Hence, the identification of leptinresponsive cells afferent to $\mathrm{GnRH}$ neurons has been of great interest to the field.

The signaling (long) form of the LepR (LepRb) is expressed in several brainstem sites and in many hypothalamic nuclei such as the arcuate, the ventromedial, the dorsomedial and the ventral premammillary $[23,24]$. In the following sections, we will discuss the recent advances in defining the leptin-responsive neural pathways involved in reproductive control.

\section{Brainstem}

In the brainstem, LepRs and leptin-induced phosphorylation of signal transducer and activator of transcription 3 (pSTAT3) are found in several nuclei, including the dorsal raphe, the lateral parabrachial, the Edinger-Westphal and the nucleus of the solitary tract (NTS) [24-26]. Of 

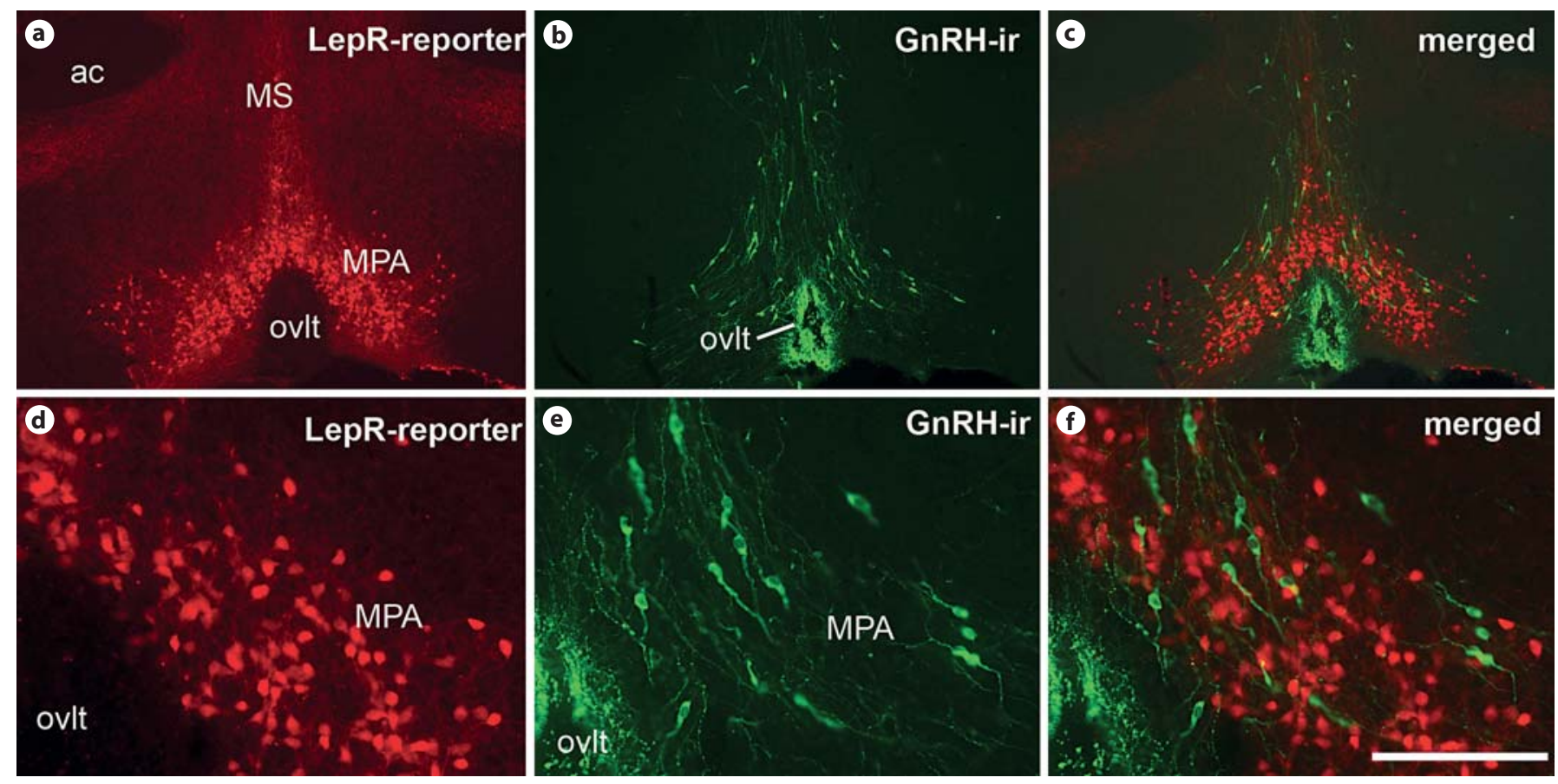

Fig. 1. Comparative distribution of neurons expressing $\mathrm{GnRH}$ and of neurons expressing LepR reporter gene. Neurons expressing LepR were visualized using LepR-IRES-Cre mice crossed with tdTomato reporter mice (B6.Cg-Gt(ROSA)26Sor ${ }^{t m 9(C A G-t d \text { Tomato } H z e} / \mathrm{J}$, $\mathrm{JAX}^{\circledR}$ mice). a-c Fluorescent photomicrograph showing the distribution of neurons expressing LepR $(\mathbf{a}, \mathbf{c})$ and of neurons ex- pressing GnRH immunoreactivity (GnRH-ir, b, c) in the medial preoptic area (MPA). d-f Higher magnification of a-c. Observe that some neurons which express LepR are intermingled with $\mathrm{GnRH}$ neurons in the MPA (c, f). ac = Anterior commissure; MS = medial septal nucleus; ovlt = vascular organ of lamina terminalis. Scale bar: a-c $800 \mu \mathrm{m}$; d-f $200 \mu \mathrm{m}$. those, special attention has been given to the NTS (fig. 2a). Neurons in the NTS receive sensory inputs conveyed by the vagus nerve and signals from circulating factors conveyed through the area postrema. The area postrema is a closely associated circumventricular organ - positioned outside the blood brain barrier - located in the dorsal border of the medial NTS. Several lines of evidence have indicated that sensory vagal inputs and circulating metabolic cues (e.g. glucose) may reach the reproductive control sites of the central nervous system via the NTS. For example, during fasting, disruption of visceral sensory signals achieved by bilateral vagotomy restored the decreased LH levels characteristic of this condition [27]. Site-specific deprivation of glucose availability in the caudal brainstem decreased LH secretion, suggesting that the area postrema may act as a glucosensor in the modulation of gonadotropins [28]. However, viral delivery of LepR into the NTS of LepR-deficient Koletsky rats did not restore their reproductive function [29]. In addition, selective deletion of LepR only from forebrain nuclei, maintaining intact the expression of LepR in the brainstem, recapitulated the reproductive deficit of leptin-signaling deficiency [22]. These findings suggest that although the caudal brainstem may carry signals from visceral inputs and glucose availability to the reproductive system, it does not relay leptin's effects in reproductive control.

\section{Paraventricular Nucleus of the Hypothalamus}

Food deprivation is a recognized condition of nutritional stress characterized by low leptin levels, decreased LH secretion and high corticotrophin-releasing hormone (CRH) levels. Interestingly, pharmacological blockade of $\mathrm{CRH}$ during fasting normalized LH levels [30]. Moreover, prevention of the decrease in leptin levels induced by fasting blunts the activation of the hypothalamus-pituitaryadrenal (HPA) axis and prevents the suppression of the reproductive axis [12]. Together, these findings suggested that CRH neurons might mediate leptin's effect to increase LH secretion in states of negative energy balance. It is well defined that the CRH neurons involved in the 

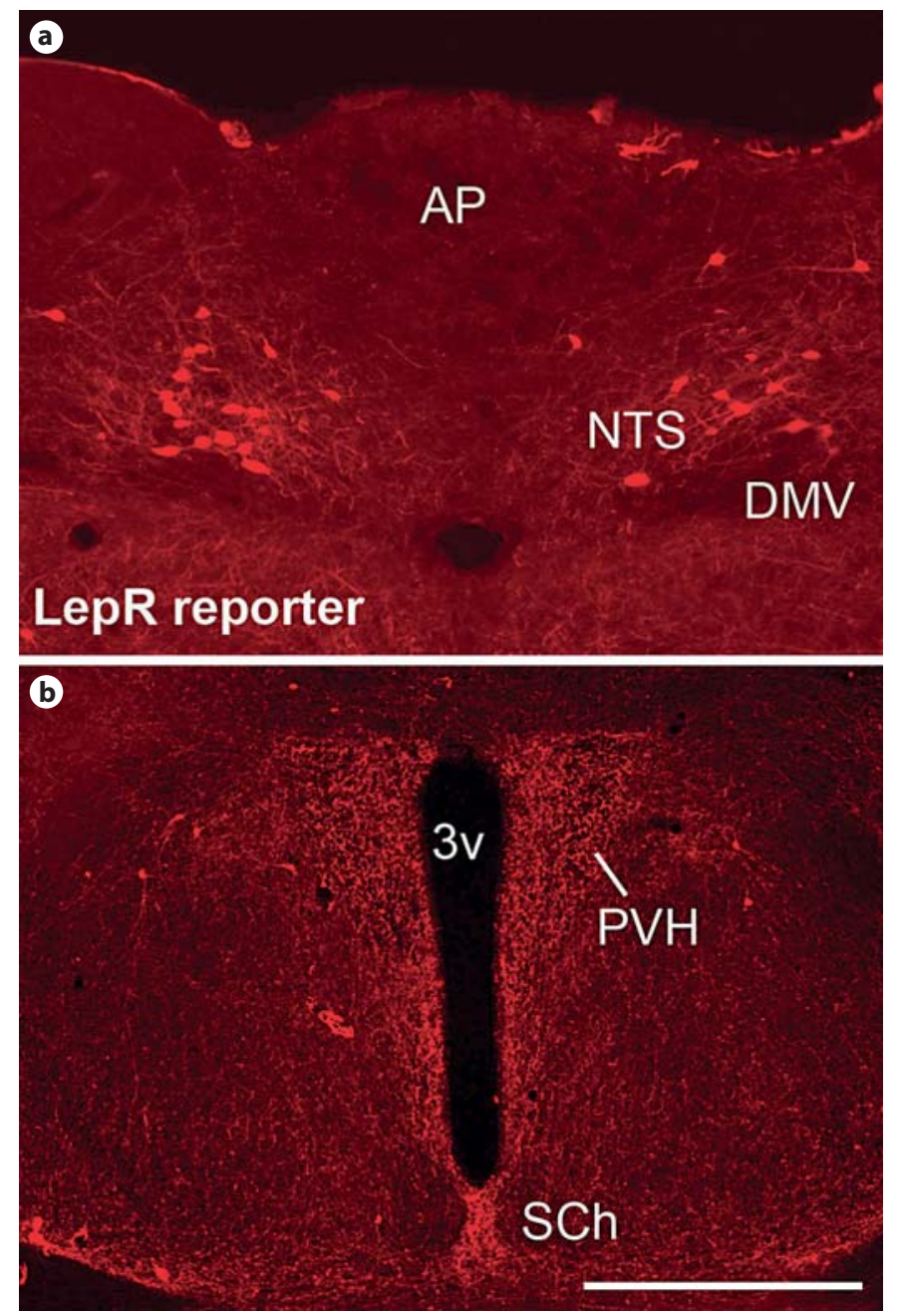

Fig. 2. Distribution of neurons expressing LepR in the NTS and PVH. Neurons expressing LepR were visualized using LepRIRES-Cre mice crossed with tdTomato reporter mice (B6.CgGt(ROSA)26Sor ${ }^{t m 9(C A G-t d T o m a t o) H z e} / \mathrm{J}, \mathrm{JAX}^{\circledR}$ mice). a Fluorescent photomicrograph showing neurons expressing LepR in the NTS. Observe the close proximity with the AP. b Fluorescent photomicrograph showing fibers originating from LepR-positive neurons in the PVH. Observe the absence of cell bodies containing the reporter gene within the limits of the PVH. $3 \mathrm{v}=$ Third ventricle; $\mathrm{DMV}=$ dorsal motor nucleus of the vagus nerve; $\mathrm{SCh}=$ suprachiasmatic nucleus. Scale bar: a $200 \mu \mathrm{m}$; b $400 \mu \mathrm{m}$.

regulation of the HPA axis are located in the paraventricular nucleus of the hypothalamus (PVH). But the expression of LepR in the PVH is very low (fig. 2b) and the colocalization of LepR in CRH neurons of the PVH is still debatable. This anatomical piece of data indicates that leptin's effect on CRH secretion is achieved via indirect pathways, which are still unrevealed.

\section{Arcuate Nucleus}

In the arcuate nucleus (Arc), LepRs are colocalized with proopiomelanocortin (POMC), neuropeptide Y/ agouti-related protein (NPY/AgRP) and Kiss1 neurons [31-33]. It has been determined that POMC and NPY/ AgRP neurons mediate most of leptin's effects in food intake, body weight and glucose homeostasis. These neuronal groups have also been investigated as likely players linking metabolism and reproduction.

The role of POMC neurons in the control of GnRH secretion and the melanocortin action mediating leptin's effect on reproduction have been subjects of intense debate with inconclusive results. For example, administration of $\alpha$-melanocyte-stimulating hormone ( $\alpha-\mathrm{MSH}$, one of POMC products) in rats may stimulate or inhibit LH secretion depending on their physiological condition [34]. The lethal yellow (Ay) mice, which display constitutive and ubiquitous expression of the agouti protein - a competitive antagonist of melanocortin receptors, exhibit obesity and abnormal estrous cycles [35]. In normally fed or leptin-treated fasted rats, melanocortin antagonists decreased the steroid-induced LH surge [36]. However, melanocortin 4 receptor (MC4R) knockout mice have no evidence of infertility [37] and pharmacological blockade of MC4Rs does not prevent the ability of leptin to positively regulate the reproductive axis of $o b / o b$ mice [38]. Moreover, mice with selective deletion of LepR from POMC neurons, from AgRP neurons, or from both POMC and AgRP neurons are fertile and produce normal litter sizes $[39,40]$. Recently, we described that deletion of both LepR and insulin receptor from POMC cells causes insulin resistance, hyperandrogenism and ovarian abnormalities with late onset of subfertility [41]. Thus, it is not yet clear whether the reproductive deficits observed in some models of melanocortin signaling deficiency are caused by disruption of a direct neuronal regulation of GnRH secretion or are secondary to their impaired metabolic function.

A role for the NPY system in reproduction has also been proposed. Central administration of NPY stimulates feeding and inhibits the reproductive axis [42]. However, the actions of NPY on GnRH secretion remain somewhat controversial. Studies in different species have suggested the existence of a complex dual action of NPY - one inhibitory and one stimulatory - through which endogenous NPY may regulate the hypothalamus-pituitary-gonad axis. These opposing effects depend on several variables, such as the steroid hormone milieu, the stages of development and changes in the 
expression of sex steroids receptors $[6,43]$. Likewise, the involvement of NPY neurons in leptin action on reproductive control is unclear. Deletion of NPY gene expression in mice also lacking leptin (ob/ob mice) improves fertility, but NPY null mice display normal reproductive function [44]. Moreover, as mentioned, deletion of LepR from AgRP/NPY neurons causes no fertility deficits [40]. Although very compelling, the experiments using genetically modified mouse models must be interpreted with caution as developmental compensatory mechanisms may have mask some of the relevant effects of POMC or NPY neurons on leptin's effect on reproductive control.

In the Arc, a subset of LepR neurons expresses Kiss1 [33]. The role of kisspeptins (the products of Kiss1 gene) and their receptor (Kiss1r, identified as GPR54) in the reproductive physiology is well established. Hypothalamic levels of Kiss1 and Kiss1r mRNA increase during pubertal development and administration of kisspeptin induces vaginal opening (in juvenile rodents), increases LH secretion and induces ovulation $[45,46]$. Kiss 1 or Kiss1r loss-of-function mutations cause hypogonadotropic hypogonadism in humans and mice [47-49]. Studies have also indicated that kisspeptin neurons are likely targets of metabolic cues as food restriction decreased Kiss1 mRNA expression in total hypothalamus or in Kiss1 neurons from the anteroventral periventricular nucleus (AVPV) [50, 51]. As mentioned, food restriction usually produces a condition of low leptin levels; therefore, changes in Kiss1 mRNA expression may be consequent to changes in circulating levels of leptin. In support to this view, leptin-deficient $o b / o b$ male mice exhibited decreased expression of Kiss1 in the Arc, which is partially restored by leptin treatment [33]. But, intriguingly, total hypothalamic expression of Kiss 1 (which includes the preoptic area and the Arc) was not changed in $o b / o b$ mice compared either to wild types or to leptin-treated $o b / o b$ mice, except when matched with food-restricted untreated $o b / o b$ mice [52]. This finding indicates that leptin may not be the major metabolic factor regulating Kiss 1 expression in conditions of negative energy balance. Another study reported that diabetic streptozotocin-injected male rats displayed decreased levels of hypothalamic Kiss1 mRNA and low circulating levels of leptin, insulin, LH and androgens [53]. Intracerebroventricular administration of leptin, but not insulin, normalized the hypothalamic Kiss 1 gene expression, and the circulating levels of $\mathrm{LH}$ and androgens. However, it is not clear whether leptin's effect to normalize Kiss1 gene expression is achieved by a direct action
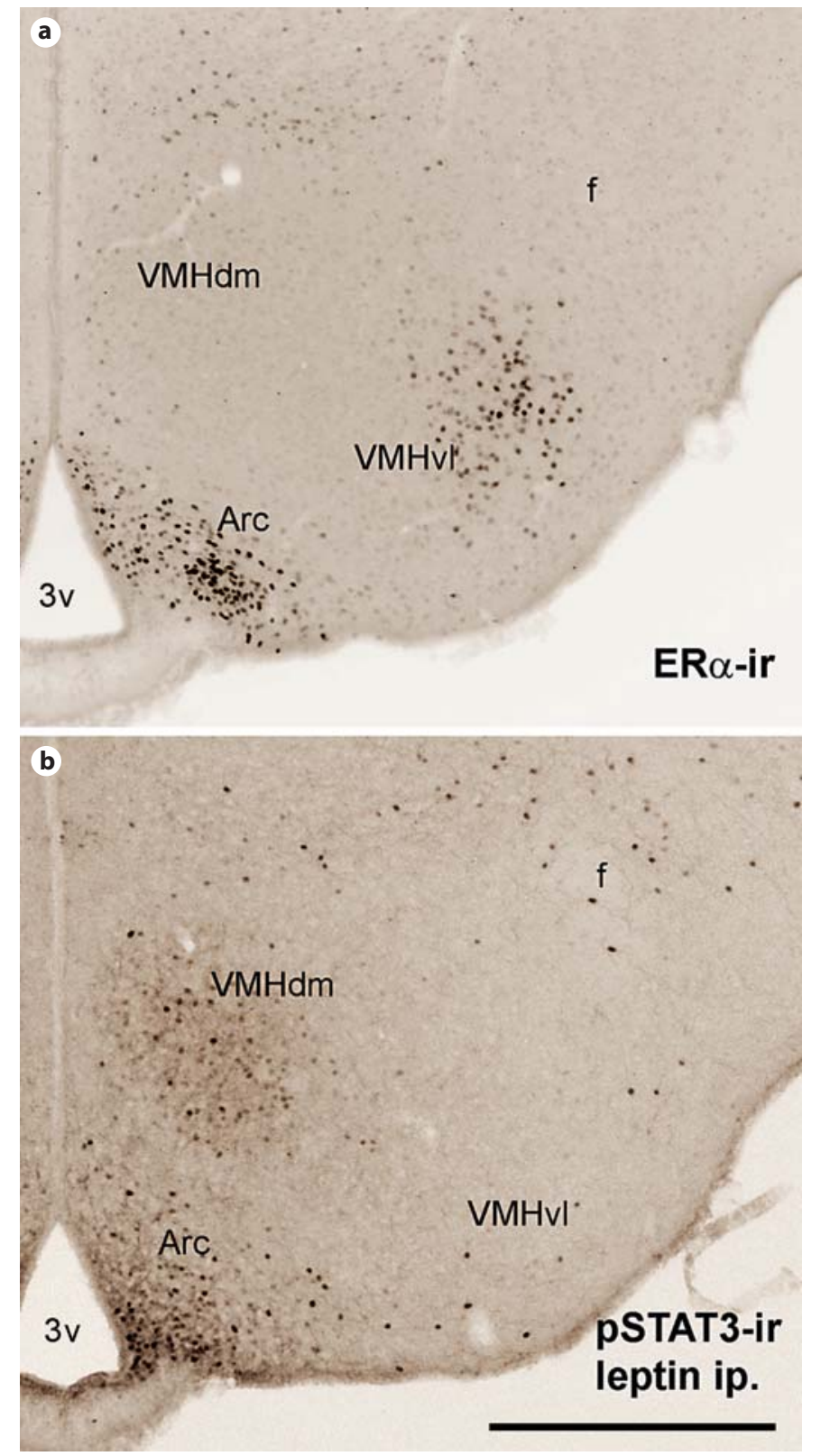

Fig. 3. Comparative distribution of estrogen receptor- $\alpha$ immunoreactivity (ER $\alpha$-ir) and leptin-responsive neurons in the $\mathrm{VMH}$. a Bright-field photomicrograph showing the distribution of ER $\alpha$ ir in the VMH. Observe that neurons expressing ER $\alpha$-ir are enriched in the ventrolateral subdivision of the VMH (VMHvl). b Bright-field photomicrograph showing the distribution of leptin-responsive neurons in the VMH. Leptin-responsive neurons were visualized by leptin-induced phosphorylation of STAT3 immunoreactivity (pSTAT3-ir). Observe that leptin-responsive neurons are enriched in the dorsomedial subdivision of the $\mathrm{VMH}$ $(\mathrm{VMHdm}) .3 \mathrm{v}=$ Third ventricle; Arc $=$ arcuate nucleus; $\mathrm{f}=$ fornix. Scale bar: $400 \mu \mathrm{m}$. 

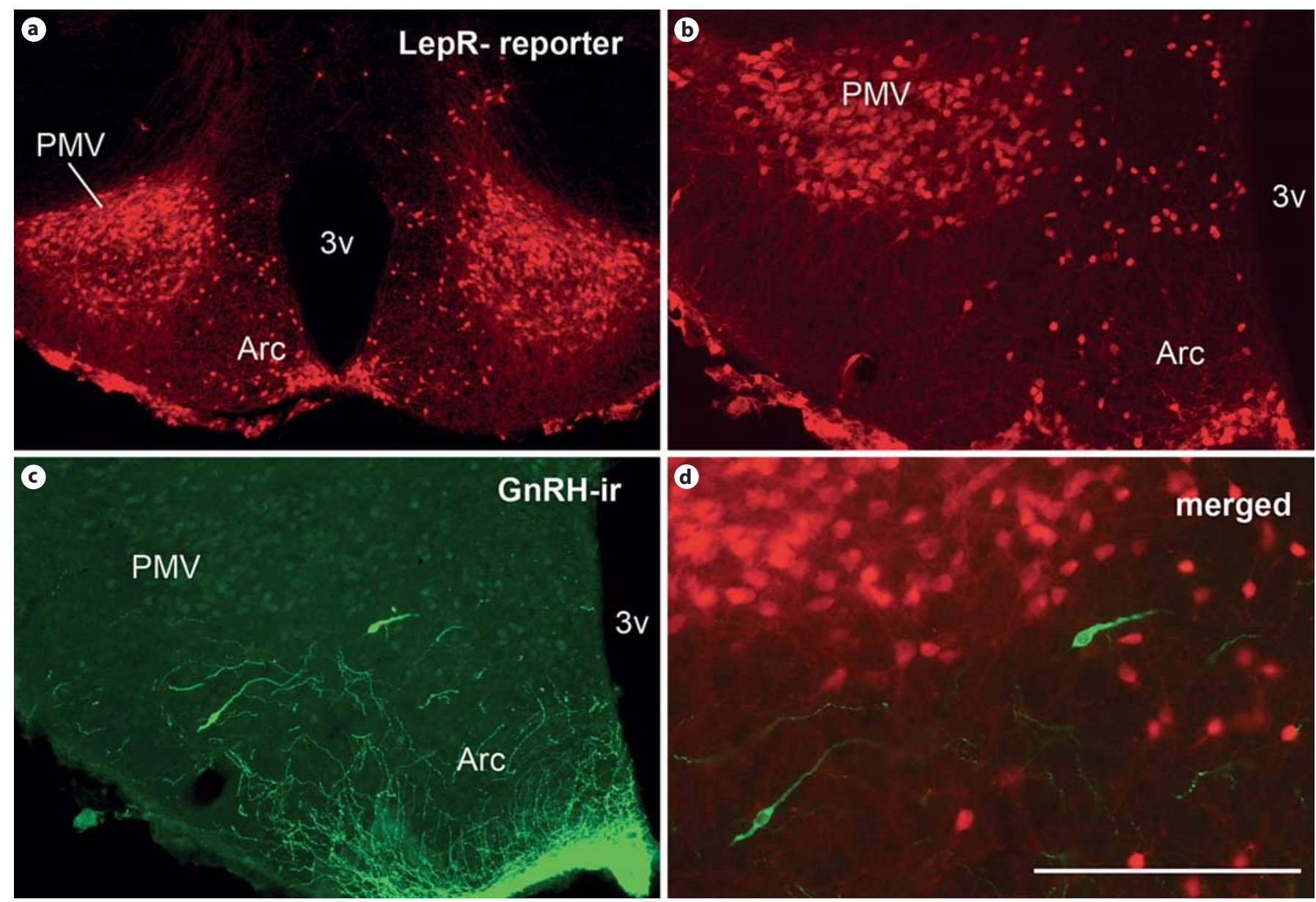

Fig. 4. Distribution of neurons expressing LepR in the PMV. Neurons expressing LepR were visualized using LepR-IRESCre mice crossed with tdTomato reporter mice (B6.Cg-Gt(ROSA) 26 Sor $^{\text {tm } 9(C A G-t d T o m a t o) H z e} / J, J A X^{\circledR}$ mice). a, b Fluorescent photomicrographs showing the distribution of LepR in the PMV. c Fluorescent photomicrographs showing the presence of $\mathrm{GnRH}$-ir in

neurons at most caudal levels of the mediobasal hypothalamus. d Higher magnification of $\mathbf{b}$ and $\mathbf{c}$ (merged image) showing that $\mathrm{GnRH}$ neurons are outside the borders of the PMV. $3 \mathrm{v}=$ Third ventricle; $\operatorname{Arc}=$ arcuate nucleus. Scale bar: a $800 \mu \mathrm{m} ; \mathbf{b}, \mathbf{c} 400$ $\mu \mathrm{m} ; \mathbf{d} 200 \mu \mathrm{m}$.

or via activation of an indirect pathway that in turn modulates Kiss1 system. Previous studies showed that stereotaxic delivery of LepR into the Arc of LepR-deficient obese Koletsky rats normalized their estrous cycle [29]. These findings suggest that neurons in the Arc, including those expressing Kiss1, play a major role. But the approach used may have generated an artificial response, as LepR may have been expressed in neurons which are not responsive to leptin under normal circumstances. In a more controlled condition, endogenous re-expression of LepR in the Arc of LepR null mice did not restore the reproductive deficits characteristic of leptin deficiency [54]. But in this experimental design injections may have not targeted Kiss1 neurons, and therefore, the role played by Kiss 1 neurons relaying leptin's effect is still unsettled.

Recently, several studies have suggested the existence of a complex interplay among Kissl, POMC and NPY/ AgRP neurons in the Arc $[55,56]$. Hence, it is been proposed that the coordinated action of this intrinsic circuitry may orchestrate the fine control of GnRH secretion by metabolic cues. Further studies are necessary in order to directly assess the physiological relevance of direct leptin signaling in Kiss1 neurons and to reveal their role in the intricate circuitry of the Arc neuronal populations. 
Table 1. Examples of studies employing genetic or pharmacological manipulations to disclose site-specific or cell-specific effects of leptin

Reproductive phenotype

Ref.

Global deletion/blockade

LepR in the brain

infertility, no pubertal development $\quad 20$

LepR in the forebrain

Ubiquitous melanocortin antagonism (Ay mouse)

infertility, no pubertal development

22

abnormal estrous cyclicity

35

Melanocortin antagonism (pharmacology)

decreased steroid-induced LH surge; normal leptin effect on

MC4R deficiency

NPY knockout

reproduction ( $o b / o b$ mice)

no deficits reported

normal fertility

44

NPY knockout in $o b / o b$ mouse

partial improvement of fertility

44

Cell-specific deletion

LepR from GnRH neurons

LepR from POMC neurons

LepR from AgRP/NPY neurons

normal fertility, normal litter size

normal fertility, normal litter size

39

normal fertility

40

normal fertility, normal litter size

40

hyperandrogenism, ovarian abnormalities and fertility deficits

normal fertility, normal litter size

41

LepR and InsR from POMC neurons

LepR from SF-1 neurons

Site-specific reactivation

Exogenous LepR in the NTS

Exogenous LepR in the Arc

Endogenous LepR in the Arc

no rescue of fertility

improvement of cyclicity in Koletsky rats

no rescue of fertility

The consequences of the manipulations for the animal reproductive function are summarized in the second column.

\section{Ventromedial Nucleus of the Hypothalamus}

The ventromedial nucleus of the hypothalamus $(\mathrm{VMH})$ is a complex structure composed of distinct subdivisions with differential connectivity. The ventrolateral subdivision of the $\mathrm{VMH}$ expresses a dense concentration of sex steroids receptors (fig. 3a) and is well described to play a role in the female sexual behavior [57-59]. Neurons in the dorsomedial subdivision of the $\mathrm{VMH}$ express the steroidogenic factor-1 (SF-1), LepR and leptin-induced pSTAT3 immunoreactivity (fig. 3b). Deletion of SF-1 selectively from the central nervous system caused disruption of $\mathrm{VMH}$ neuronal connectivity and impairment of the female reproductive function [60]. Therefore, the $\mathrm{VMH}$ is thought to be a potential leptin target in reproductive control. Using the SF-1 gene promoter to drive Cre expression specifically in VMH neurons, two different groups have demonstrated the physiologic role played by the VMH in leptin's effect on energy homeostasis [61, 62]. However, deletion of LepR selectively from VMH neurons did not produce any reproductive deficits in these mice, indicating that leptin signaling in the $\mathrm{VMH}$ is not required for leptin's effect on reproduction.

Hypothalamic Sites of Leptin Action

\section{Ventral Premammillary Nucleus}

The ventral premammillary nucleus (PMV) expresses a dense collection of LepR (fig. 4) and leptin-responsive neurons $[23,63,64]$. However, it has remained an unrecognized leptin target and the physiological role played by the PMV in mediating leptin's effects has only recently started to be systematically investigated $[64,65]$. The PMV expresses sex steroids receptors $[59,66]$ and innervates brain sites related to reproductive control, to the vomeronasal system and to the sexually dimorphic circuitry $[67,68]$. Using standard tract tracing, we showed that terminals from PMV neurons were in close apposition with GnRH cells in the preoptic area [68]. This preliminary observation was subsequently confirmed by different laboratories using genetically engineered mouse models [64, 69]. Additionally, Leshan et al. [64] demonstrated that, in fact, the innervation of GnRH cells by PMV fibers originates from neurons expressing LepR.

The PMV neurons display Fos immunoreactivity - a maker of neuronal activation - following copulation [70]. But copulation is a complex process making the in- 
creased Fos expression difficult to interpret. Subsequent studies showed that the exposure to female odors alone is sufficient to induce Fos in PMV neurons [64, 71-73]. In response to opposite sex odors, male and female from many species exhibit increased circulating levels of gonadotropins $[74,75]$. In rats, this effect was suppressed by lesions of the PMV $[75,76]$. Together, these findings suggested that the PMV integrates sexually relevant (odor) environmental signals, the reproductive status (sex steroids) and metabolic cues (leptin). We then hypothesized that PMV neurons relay leptin's effect to increase LH secretion during states of negative energy balance.

As a first approach to test our hypothesis, we performed bilateral excitotoxic lesions of the PMV and assessed different parameters of the female reproductive physiology [65]. PMV-lesioned rats displayed a clear disruption of the estrous cycle for 2 to 3 weeks. After this period, their cyclicity was normalized, but lesions of the PMV caused a permanent deficit in the female's neuroendocrine profile. On proestrus, PMV-lesioned rats exhibited reduction of estradiol and LH levels, of GnRH mRNA expression and a blunted activation of GnRH and AVPV neurons. Of note, in PMV-lesioned fasted rats, leptin treatment failed to increase LH levels. Our findings indicate that PMV neurons are required for leptin stimulation of LH secretion in fasted rats. However, it is worth mentioning that the PMV is comprised of a heterogeneous population of neurons, and therefore, the effects produced by the excitotoxic lesions may be the consequence of disruption of pathways not related to leptin's physiology. Thus, a more selective approach in which leptin signaling is either blocked or endogenously re-expressed in PMV neurons is necessary to determine its physiologic relevance for leptin's effect on reproduction.

\section{Conclusion and Future Directions}

The coordination of the reproductive control is essential for the species survival. As noted by different authors, the control of the reproductive physiology involves redundant brain pathways and a number of endocrine players. In this review, we discussed the brain sites potentially involved in leptin's physiological effects in the reproductive neuroendocrine axis. The definitive answer has not been offered, but the availability of genetically engineered mouse models and site-specific manipulations of defined genes have brought a considerable advance to the field (table 1). Neuron-specific targeting with the use of transgenic mouse lines and viral vector delivery in defined brain sites will allow the identification of specific neuronal population(s) relaying leptin's effect in reproductive control. Importantly, these approaches must allow the identification of relevant site(s) of leptin effect during development and in adult life. It is also hoped that modern technologies using in vivo and in vitro approaches to assess site-specific epigenetic changes or alterations in gene expression under metabolic challenges will bring advances to the field. The identification of the related neuronal populations and the molecular basis of leptin's effect on reproductive control is a fundamental step for the understanding of a variety of conditions of impaired fertility derived from metabolic dysfunctions.

\section{Acknowledgements}

This work was supported by NIH R01HD061539 and Foundation for Prader-Willi Research (to C.F.E.), by the National Council for Scientific and Technological Development/CNPq-Brazil 201804/2008-5 (to R.F.), and by the President's Council Award and the Regent's Research Award (UTSW, Dallas, Tex., USA, to C.F.E.).

\section{References}

$>1$ Kennedy GC: Interactions between feeding behavior and hormones during growth. Ann NY Acad Sci 1969;157:1049-1061.

-2 Frisch RE, McArthur JW: Menstrual cycles: fatness as a determinant of minimum weight for height necessary for their maintenance or onset. Science 1974;185:949-951.

$\checkmark 3$ Frisch RE: Fatness, menarche, and female fertility. Perspect Biol Med 1985;28:611-633.

4 Plant TM, Barker A, Gibb ML: Neurobiological mechanisms of puberty in higher primates. Hum Reprod Update 2004;10:67-77.
5 Cunningham MJ, Clifton DK, Steiner RA: Leptin's actions on the reproductive axis: Perspectives and mechanisms. Biol Reprod 1999;60:216-222.

6 Hill JW, Elmquist JK, Elias CF: Hypothalamic pathways linking energy balance and reproduction. Am J Physiol Endocrinol Metab 2008;294:E827-E832.

7 Zhang Y, Proenca R, Maffei M, Barone M, Leopold L, Friedman JM: Positional cloning of the mouse obese gene and its human homologue [published erratum appears in $\mathrm{Na}$ ture 199530;374:479; see comments]. Nature 1994;372:425-432.
8 Tartaglia LA, Dembski M, Weng X, et al: Identification and expression cloning of a leptin receptor, ob-r. Cell 1995;83:12631271.

$\checkmark 9$ Chehab FF, Lim ME, Lu R: Correction of the sterility defect in homozygous obese female mice by treatment with the human recombinant leptin. Nat Genet 1996;12:318-320.

10 Barash IA, Cheung CC, Weigle DS, Ren H, Kabigting EB, Kuijper JL, Clifton DK, Steiner RA: Leptin is a metabolic signal to the reproductive system. Endocrinology 1996; 137:3144-3147. 
-11 Farooqi IS, Matarese G, Lord GM, Keogh JM, 23 Elmquist JK, Bjorbaek C, Ahima RS, Flier JS, Lawrence E, Agwu C, Sanna V, Jebb SA, Perna F, Fontana S, Lechler RI, DePaoli AM, O'Rahilly S: Beneficial effects of leptin on obesity, T cell hyporesponsiveness, and neuroendocrine/metabolic dysfunction of human congenital leptin deficiency. J Clin Invest 2002;110:1093-1103.

12 Ahima RS, Prabakaran D, Mantzoros C, Qu D, Lowell B, Maratos-Flier E, Flier JS: Role of leptin in the neuroendocrine response to fasting. Nature 1996;382:250-252.

13 Nagatani S, Guthikonda P, Thompson RC, Tsukamura H, Maeda KI, Foster DL: Evidence for GnRH regulation by leptin: leptin administration prevents reduced pulsatile $\mathrm{lh}$ secretion during fasting. Neuroendocrinology 1998;67:370-376.

- 14 Gonzalez LC, Pinilla L, Tena-Sempere M, Aguilar E: Leptin(116-130) stimulates prolactin and luteinizing hormone secretion in fasted adult male rats. Neuroendocrinology 1999;70:213-220

-15 Welt CK, Chan JL, Bullen J, Murphy R, Smith P, DePaoli AM, Karalis A, Mantzoros CS: Recombinant human leptin in women with hypothalamic amenorrhea. N Engl J Med 2004;351:987-997.

16 Qiu J, Ogus S, Mounzih K, Ewart-Toland A, Chehab FF: Leptin-deficient mice backcrossed to the $\mathrm{Balb} / \mathrm{cj}$ genetic background have reduced adiposity, enhanced fertility, normal body temperature, and severe diabetes. Endocrinology 2001;142:3421-3425.

-17 Schneider JE: Energy balance and reproduction. Physiol Behav 2004;81:289-317.

-18 Szymanski LA, Schneider JE, Friedman MI, Ji H, Kurose Y, Blache D, Rao A, Dunshea FR, Clarke IJ: Changes in insulin, glucose and ketone bodies, but not leptin or body fat content precede restoration of luteinising hormone secretion in ewes. J Neuroendocrinol 2007;19:449-460.

- 19 Zamorano PL, Mahesh VB, De Sevilla LM, Chorich LP, Bhat GK, Brann DW: Expression and localization of the leptin receptor in endocrine and neuroendocrine tissues of the rat. Neuroendocrinology 1997;65:223-228.

-20 de Luca C, Kowalski TJ, Zhang Y, Elmquist JK, Lee C, Kilimann MW, Ludwig T, Liu SM, Chua SC Jr: Complete rescue of obesity, diabetes, and infertility in $\mathrm{db} / \mathrm{db}$ mice by neuron-specific lepr-b transgenes. J Clin Invest 2005;115:3484-3493.

-21 Magni P, Vettor R, Pagano C, Calcagno A, Beretta E, Messi E, Zanisi M, Martini L, Motta M: Expression of a leptin receptor in immortalized gonadotropin-releasing hormone-secreting neurons. Endocrinology 1999;140:1581-1585.

-22 Quennell JH, Mulligan AC, Tups A, Liu X, Phipps SJ, Kemp CJ, Herbison AE, Grattan DR, Anderson GM: Leptin indirectly regulates gonadotropin-releasing hormone neuronal function. Endocrinology 2009;150: 2805-2812.
Saper CB: Distributions of leptin receptor mrna isoforms in the rat brain. J Comp Neurol 1998;395:535-547.

24 Scott MM, Lachey JL, Sternson SM, Lee CE, Elias CF, Friedman JM, Elmquist JK: Leptin targets in the mouse brain. J Comp Neurol 2009;514:518-532.

25 Caron E, Sachot C, Prevot V, Bouret SG: Distribution of leptin-sensitive cells in the postnatal and adult mouse brain. J Comp Neurol 2010;518:459-476.

26 Huo L, Maeng L, Bjorbaek C, Grill HJ: Leptin and the control of food intake: Neurons in the nucleus of the solitary tract are activated by both gastric distension and leptin. Endocrinology 2007;148:2189-2197.

27 Cagampang FR, Maeda K, Ota K: Involvement of the gastric vagal nerve in the suppression of pulsatile luteinizing hormone release during acute fasting in rats. Endocri-

28 Murahashi K, Bucholtz DC, Nagatani S, Tsukahara S, Tsukamura H, Foster DL, Maeda KI: Suppression of luteinizing hormone pulses by restriction of glucose availability is mediated by sensors in the brain stem. Endocrinology 1996;137:1171-1176.

29 Keen-Rhinehart E, Kalra SP, Kalra PS: AAVmediated leptin receptor installation improves energy balance and the reproductive status of obese female koletsky rats. Peptides 2005;26:2567-2578.

-30 Tsukahara S, Tsukamura H, Foster DL, Maeda KI: Effect of corticotropin-releasing hormone antagonist on oestrogen-dependent glucoprivic suppression of luteinizing hormone secretion in female rats. J Neuroendocrinol 1999;11:101-105.

31 Baskin DG, Breininger JF, Schwartz MW: Leptin receptor mRNA identifies a subpopulation of neuropeptide $\mathrm{Y}$ neurons activated by fasting in rat hypothalamus. Diabetes 1999;48:828-833.

32 Cheung CC, Clifton DK, Steiner RA: Proopiomelanocortin neurons are direct targets for leptin in the hypothalamus. Endocrinology 1997;138:4489-4492.

33 Smith JT, Acohido BV, Clifton DK, Steiner RA: Kiss-1 neurones are direct targets for leptin in the ob/ob mouse. J Neuroendocrinol 2006;18:298-303.

34 Celis ME: Release of LH in response to alphaMSH administration. Acta Physiol Pharmacol Latinoam 1985;35:281-290.

35 Granholm NH, Jeppesen KW, Japs RA: Progressive infertility in female lethal yellow mice (ay/a; strain c57bl/6j). J Reprod Fertil 1986;76:279-287.

36 Watanobe H, Schiöth HB, Wikberg JES, Suda T: The melanocortin 4 receptor mediates leptin stimulation of luteinizing hormone and prolactin surges in steroid-primed ovariectomized rats. Biochem Biophys Res Commun 1999;257:860-864. nology 1992;130:3003-3006.
37 Huszar D, Lynch CA, Fairchild-Huntress V, Dunmore JH, Fang Q, Berkemeier LR, Gu W, Kesterson RA, Boston BA, Cone RD, Smith FJ, Campfield LA, Burn P, Lee F: Targeted disruption of the melanocortin-4 receptor results in obesity in mice. Cell 1997;88:131141.

38 Hohmann JG, Teal TH, Clifton DK, Davis J, Hruby VJ, Han G, Steiner RA: Differential role of melanocortins in mediating leptin's central effects on feeding and reproduction. Am J Physiol Regul Integr Comp Physiol 2000;278:R50-R59.

39 Balthasar N, Coppari R, McMinn J, Liu SM, Lee CE, Tang V, Kenny CD, McGovern RA, Chua SC, Jr., Elmquist JK, Lowell BB: Leptin receptor signaling in pomc neurons is required for normal body weight homeostasis. Neuron 2004;42:983-991.

40 van de Wall E, Leshan R, Xu AW, Balthasar N, Coppari R, Liu SM, Jo YH, MacKenzie RG, Allison DB, Dun NJ, Elmquist J, Lowell BB, Barsh GS, de Luca C, Myers MG Jr, Schwartz GJ, Chua SC Jr: Collective and individual functions of leptin receptor modulated neurons controlling metabolism and ingestion. Endocrinology 2007;149:17731785.

41 Hill JW, Elias CF, Fukuda M, Williams KW, Berglund ED, Holland WL, Cho YR, Chuang JC, Xu Y, Choi M, Lauzon D, Lee CE, Coppari R, Richardson JA, Zigman JM, Chua S, Scherer PE, Lowell BB, Bruning JC, Elmquist JK: Direct insulin and leptin action on proopiomelanocortin neurons is required for normal glucose homeostasis and fertility. Cell Metab 2010;11:286-297.

42 Clark JT, Kalra PS, Kalra SP: Neuropeptide Y stimulates feeding but inhibits sexual behavior in rats. Obes Res 1985;5:275-283.

43 Wójcik-Gładysz A, Polkowska J: Neuropeptide $\mathrm{Y}$ - a neuromodulatory link between nutrition and reproduction at the central nervous system level. Reprod Biol 2006;6:21-28.

-44 Erickson JC, Hollopeter G, Palmiter RD: Attenuation of the obesity syndrome of ob/ob mice by the loss of neuropeptide Y [see comments]. Science 1996;274:1704-1707.

45 Navarro VM, Fernandez-Fernandez R, Castellano JM, Roa J, Mayen A, Barreiro ML, Gaytan F, Aguilar E, Pinilla L, Dieguez C, Tena-Sempere M: Advanced vaginal opening and precocious activation of the reproductive axis by kiss- 1 peptide, the endogenous ligand of gpr54. J Physiol 2004;561: 379-386.

46 Tena-Sempere M: The roles of kisspeptins and $\mathrm{G}$ protein-coupled receptor-54 in pubertal development. Curr Opin Pediatr 2006; 18: 442-447.

47 de Roux N, Genin E, Carel JC, Matsuda F, Chaussain JL, Milgrom E: Hypogonadotropic hypogonadism due to loss of function of the kiss1-derived peptide receptor gpr54. Proc Natl Acad Sci USA 2003;100:1097210976. 
-48 Seminara SB, Messager S, Chatzidaki EE, Thresher RR, Acierno JS, Jr., Shagoury JK, Bo-Abbas Y, Kuohung W, Schwinof KM, Hendrick AG, Zahn D, Dixon J, Kaiser UB, Slaugenhaupt SA, Gusella JF, O'Rahilly S, Carlton MB, Crowley WF Jr, Aparicio SA, Colledge WH: The gpr54 gene as a regulator of puberty. N Engl J Med 2003;349:16141627.

49 Colledge WH: Transgenic mouse models to study gpr54/kisspeptin physiology. Peptides 2009;30:34-41.

50 Castellano JM, Navarro VM, FernandezFernandez R, Nogueiras R, Tovar S, Roa J, Vazquez MJ, Vigo E, Casanueva FF, Aguilar E, Pinilla L, Dieguez C, Tena-Sempere M: Changes in hypothalamic kiss-1 system and restoration of pubertal activation of the reproductive axis by kisspeptin in undernutrition. Endocrinology 2005;146:3917-3925.

-51 Kalamatianos T, Grimshaw SE, Poorun R, Hahn JD, Coen CW: Fasting reduces kiss-1 expression in the anteroventral periventricular nucleus (AVPV): effects of fasting on the expression of kiss-1 and neuropeptide $\mathrm{Y}$ in the AVPV or arcuate nucleus of female rats. J Neuroendocrinol 2008;20:1089-1097.

- 52 Luque RM, Kineman RD, Tena-Sempere M: Regulation of hypothalamic expression of kiss-1 and gpr 54 genes by metabolic factors: analyses using mouse models and a cell line. Endocrinology 2007; 148:4601-4611.

53 Castellano JM, Navarro VM, FernandezFernandez R, Roa J, Vigo E, Pineda R, Dieguez C, Aguilar E, Pinilla L, Tena-Sempere M: Expression of hypothalamic kiss-1 system and rescue of defective gonadotropic responses by kisspeptin in streptozotocin-induced diabetic male rats. Diabetes 2006;55: 2602-2610

-54 Coppari R, Ichinose M, Lee CE, Pullen AE, Kenny CD, McGovern RA, Tang V, Liu SM, Ludwig T, Chua SC Jr, Lowell BB, Elmquist JK: The hypothalamic arcuate nucleus: a key site for mediating leptin's effects on glucose homeostasis and locomotor activity. Cell Metabolism 2005;1:63-72.

- 55 Backholer K, Smith JT, Rao A, Pereira A, Iqbal J, Ogawa S, Li Q, Clarke IJ: Kisspeptin cells in the ewe brain respond to leptin and communicate with neuropeptide $y$ and proopiomelanocortin cells. Endocrinology 2010; 151:2233-2243.
Fu L-Y, van den Pol AN: Kisspeptin directly excites anorexigenic proopiomelanocortin neurons but inhibits orexigenic neuropeptide Y cells by an indirect synaptic mechanism. J Neurosci 2010;30:10205-10219.

57 Davis PG, McEwen BS, Pfaff DW: Localized behavioral effects of tritiated estradiol implants in the ventromedial hypothalamus of female rats. Endocrinology 1979;104:898903.

58 Simerly RB, Chang C, Muramatsu M, Swanson LW: Distribution of androgen and estrogen receptor mRNA-containing cells in the rat brain: an in situ hybridization study. J Comp Neurol 1990;294:76-95.

59 Merchenthaler I, Lane MV, Numan S, Dellovade TL: Distribution of estrogen receptor alpha and beta in the mouse central nervous system: In vivo autoradiographic and immunocytochemical analyses. J Comp Neurol 2004;473:270-291.

60 Kim KW, Li S, Zhao H, Peng B, Tobet SA, Elmquist JK, Parker KL, Zhao L: CNS-specific ablation of steroidogenic factor 1 results in impaired female reproductive function. Mol Endocrinol 2010;24:1240-1250.

-61 Dhillon H, Zigman JM, Ye C, Lee CE, McGovern RA, Tang V, Kenny CD, Christiansen LM, White RD, Edelstein EA, Coppari R, Balthasar N, Cowley MA, Chua S Jr, Elmquist JK, Lowell BB: Leptin directly activates sf 1 neurons in the $\mathrm{VMH}$, and this action by leptin is required for normal bodyweight homeostasis. Neuron 2006;49:191203.

62 Bingham NC, Anderson KK, Reuter AL, Stallings NR, Parker KL: Selective loss of leptin receptors in the ventromedial hypothalamic nucleus results in increased adiposity and a metabolic syndrome. Endocrinology 2008;149:2138-2148.

63 Elias CF, Kelly JF, Lee CE, Ahima RS, Drucker DJ, Saper CB, Elmquist JK: Chemical characterization of leptin-activated neurons in the rat brain. J Comp Neurol 2000;423: 261-281.

64 Leshan RL, Louis GW, Jo Y-H, Rhodes CJ, Munzberg H, Myers MG Jr: Direct innervation of GnRH neurons by metabolic- and sexual odorant-sensing leptin receptor neurons in the hypothalamic ventral premammillary nucleus. J Neurosci 2009;29:31383147.

65 Donato J, Jr, Silva RJ, Sita LV, Lee S, Lee C, Lacchini S, Bittencourt JC, Franci CR, Canteras NS, Elias CF: The ventral premammillary nucleus links fasting-induced changes in leptin levels and coordinated luteinizing hormone secretion. J Neurosci 2009;29: $5240-5250$.
66 Simerly RB: Hormonal control of neuropeptide gene expression in sexually dimorphic olfactory pathways. Trends Neurosci 1990; 13:104-110.

-67 Canteras NS, Simerly RB, Swanson LW: Projections of the ventral premammillary nucleus. J Comp Neurol 1992;324:195-212.

68 Rondini TA, Baddini SP, Sousa LF, Bittencourt JC, Elias CF: Hypothalamic cocaineand amphetamine-regulated transcript neurons project to areas expressing gonadotropin releasing hormone immunoreactivity and to the anteroventral periventricular nucleus in male and female rats. Neuroscience 2004;125:735-748.

69 Boehm U, Zou Z, Buck LB: Feedback loops link odor and pheromone signaling with reproduction. Cell 2005;123:683-695.

70 Kollack-Walker S, Newman SW: Mating and agonistic behavior produce different patterns of Fos immunolabeling in the male Syrian hamster brain. Neuroscience 1995;66: 721-736.

71 Yokosuka M, Matsuoka M, Ohtani-Kaneko R, Iigo M, Hara M, Hirata K, Ichikawa M: Female-soiled bedding induced Fos immunoreactivity in the ventral part of the premammillary nucleus (PMV) of the male mouse. Physiol Behav 1999;68:257-261.

72 Cavalcante JC, Bittencourt JC, Elias CF: Female odors stimulate cart neurons in the ventral premammillary nucleus of male rats. Physiol Behav 2006;88:160-166.

73 Donato J Jr, Cavalcante JC, Silva RJ, Teixeira AS, Bittencourt JC, Elias CF: Male and female odors induce Fos expression in chemically defined neuronal population. Physiology \& Behavior 2010;99:67-77.

74 Coquelin A, Clancy AN, Macrides F, Noble EP, Gorski RA: Pheromonally induced release of luteinizing hormone in male mice: involvement of the vomeronasal system. J Neurosci 1984;4:2230-2236.

75 Beltramino C, Taleisnik S: Release of LH in the female rat by olfactory stimuli: effect of the removal of the vomeronasal organs or lesioning of the accessory olfactory bulbs. Neuroendocrinology 1983;36:53-58.

76 Beltramino C, Taleisnik S: Ventral premammillary nuclei mediate pheromonal-induced LH release stimuli in the rat. Neuroendocrinology 1985;41:119-124. 